When the straight part of the curves for whole serum (Fig. I) was extrapolated in the same way to the abscissa, the total antitrypsin value found with BAPNA was 47 $\mu \mathrm{g} / 50 \mu \mathrm{l}$ and with casein $57 \mu \mathrm{g} / 50 \mu \mathrm{l}$ serum, i.e. a difference in this serum of $0.2 \mathrm{mg} / \mathrm{ml}$. Particularly in the determination of the total antitrypsin activity with $\alpha_{1}$-antitrypsin deficiency it is important to take into account the variation of the results with the trypsin substrates used.

Department of Clinical Chemistry, P. O. GANROT Malmö General Hospital, University of Lund (Sweden)

I B. J. Haverback, B. Dyce, H. F. Bundy, S. K. Wirtschafter and H. A. Edmondson, J. Clin. Invest., 4 I (1962) 972.

2 J. W. Mehl, W. O'Connell and J. De Groot, Science, I45 (I964) 82 I.

3 E. L. Khoporova, K. N. Veremeyenko and A. A. Antonyan, Ukv. Biokhim. Zh., $36(5964) 613$.

4 P. O. Ganrot, Clin. Chim. Acta, I 3 (Ig66) xxx.

5 H. F. Bundy and J. W. Mehl, J. Clin. Invest., 37 (1958) 947.

6 M. Bier and F. F. Nord, Arch. Biochem. Biophys., 3I (I95I) 335.

7 M. Steinbuch, Vox Sanguinis, 9 (1964) 96.

Received September 2oth, I965

Clin. Chim. Acta, 13 (1966) 518-52 I

\title{
Stability of haemiglobincyanide reference solutions
}

In I962, Zijlstra and Van Kampen ${ }^{1}$ described the preparation of a haemiglobincyanide ( $\mathrm{HiCN})$ reference solution. The haemoglobin content of this reference solution is calculated based on $\varepsilon_{\text {HicN }}^{540}=$ II.O (ref. 2). These reference solutions were stated to remain stable for at least one year and have been proposed as an international reference standard ${ }^{3}$. This study was undertaken to acquire an idea of the long-term stability of these solutions when stored in the dark, at $4^{\circ}$ and at room temperature.

The HiCN reference solutions used have been, except for solution I, prepared by the Dutch Institute of Public Health according to the specifications laid down by $\mathrm{Zijlstra}$ and Van Kampen ${ }^{1}$. The solutions have been issued in capped Io-ml brown glass ampoules for the calibration of filter photometers since $196 \mathbf{I}$. As the sample dilution advocated in the $\mathrm{HiCN}$ method ${ }^{4}$ is $\mathrm{I}: 25 \mathrm{I},(20 \mu \mathrm{l}$ of blood in $5.0 \mathrm{ml}$ of reagent), a haemoglobin content of $5^{\circ}$ to $60 \mathrm{mg} \%$ was chosen for the reference solutions allowing calibration of photometers in the region of I2.6 to I5.I $\mathrm{g} \%$ haemoglobin. Solution 7 was therefore not issued for calibration purposes. All reference solutions were stored, where possible, in the dark at $4^{\circ}$ and at room temperature. Solution $I$ was stored at room temperature only, solutions 7,8 and io at $4^{\circ}$ only, as not enough ampoules would otherwise have been available for a long-term study. The optical density at $\lambda=540 \mathrm{~nm}$, later also at $\lambda=504 \mathrm{~nm}$, was checked regularly with a Beckman DU spectrophotometer, layer thickness $1.000 \mathrm{~cm}$, half intensity band width 0.52 and $0.42 \mathrm{~nm}$ at $\lambda=540 \mathrm{~nm}$ and $\lambda=504 \mathrm{~nm}$ respectively. The wavelength calibration of the spectrophotometer was checked regularly using the mercury emission spectrum. 


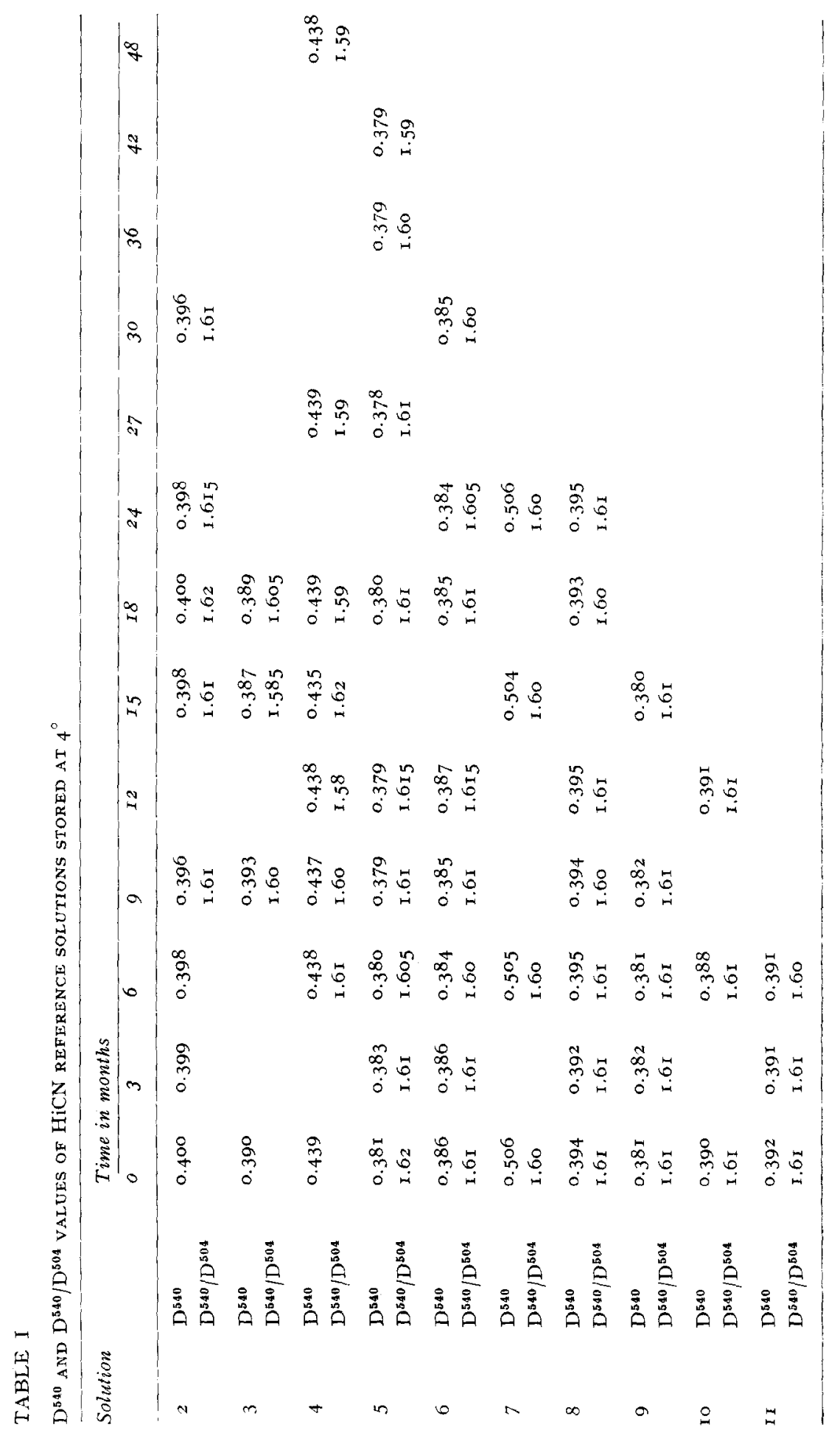

Clin. Chim. Acta, I3 (1966) 521-524 


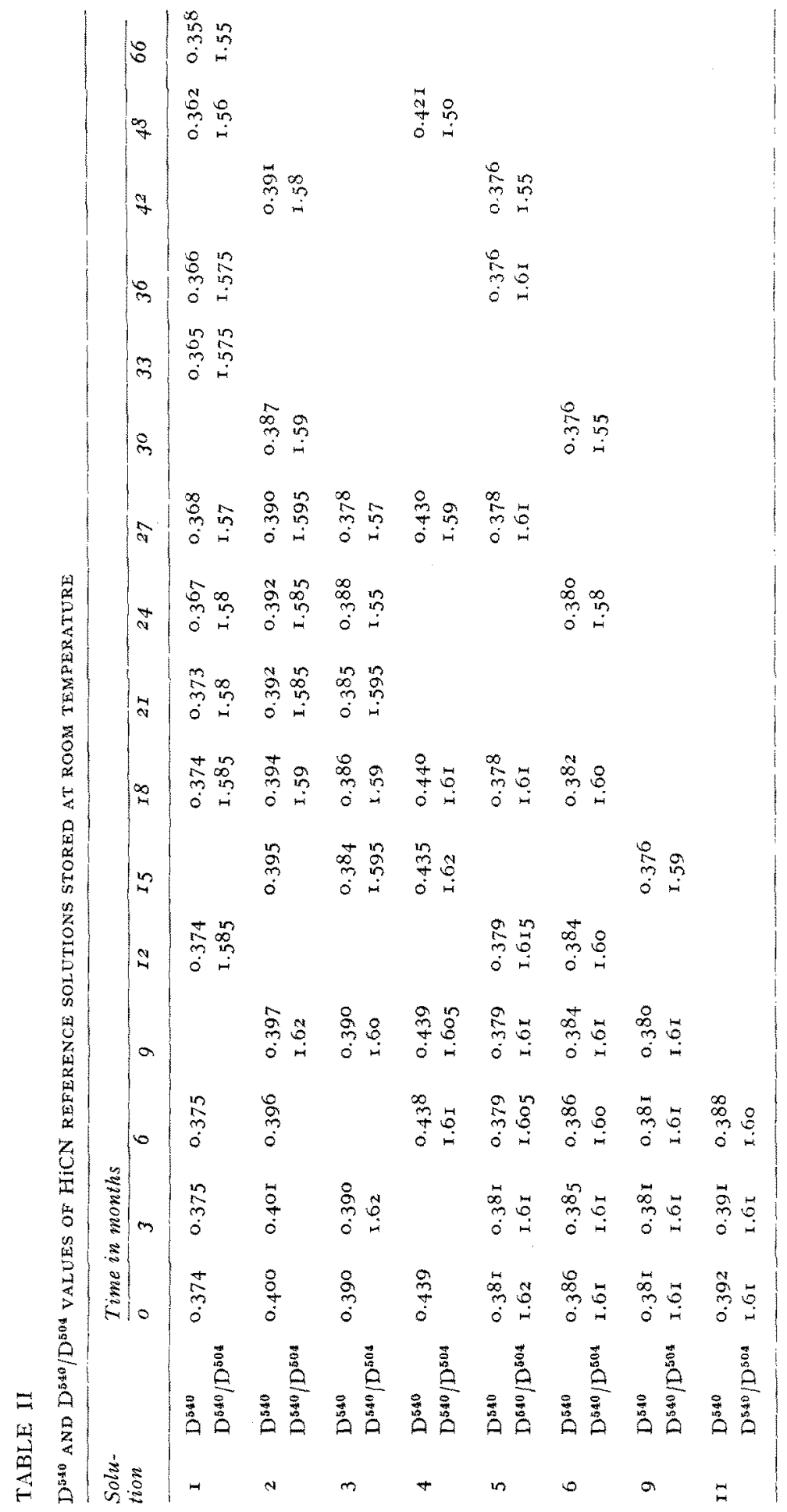


In Table $I$ the $D^{540}$ and $D^{540} / D^{504}$ values 5 are presented for the reference solutions stored at $4^{\circ}$. In Table II these values for the solutions stored at room temperature are shown. The results given in Table I show that, when stored in the dark at $4^{\circ}$, the $\mathrm{HiCN}$ reference solutions seem to remain stable for at least 3 years. When stored at room temperature, however, these same solutions generally deteriorate after about I $\frac{1}{2}$ years, as clearly follows from Table II.

The checking of $\mathrm{HiCN}$ reference solutions is being continued to establish the absolute upper limit of stability on storing.

Department of Chemical Physiology,

O. W. VAN ASSENDELFT

University of Groningen,

W. G. ZiJLSTRA

Clinical Chemical Laboratory, Diaconessenhuis, Groningen

E. J. VAN KAMPEN

and Rijksinstitunt voor de Volksgezondheid,

A. H. HoLTZ

Utrecht (The Netherlands)

I W. G. Zijlstra and E. J. van Kampen, Chin. Chim. Acta, 7 (1962) 96.

2 W. G. Zijustra and E. J. van Kampen, Clin. Chim. Acta, 5 (1960) 7 I 9.

3 CH. G. DE Boroviczény, Bibl. Haematol, 2 I (1965) 88.

4 E. J. van Kampen and W. G. Zijlstra, Clin. Chim. Acta, 6 (196I) $53^{8}$.

5 W. G. Zijlstra and E. J. van Kampen, Bibl. Haematol., 2 I (1965) 96.

Received November I2th, I965

Clin. Chim. Acta, I 3 (1966) $52 \mathrm{I}-524$

\section{An evaluation of the Reitman-Frankel method for the determination of serum glutamic oxalacetic transaminase}

The Reitman--Frankel ${ }^{1}$ method for the determination of the clinically valuable glutamic oxalacetic transaminase activity of human serum is one of the most commonly used procedures for this assay. However the validity of the results obtained does not appear to have been unequivocally established, at least in the following respects: (I) the accuracy and precision of repeated analysis over a period of time on the same serum sample which would be of importance in following changes in level of the enzyme; (2) the accuracy and comparability of assays conducted with commercially prepared reagents and standard solutions now in widespread use; (3) the factors for calculation of enzyme activity as Reitman-Frankel units from the colorimetrically determined pyruvate which is produced after incubation of the enzyme and substrate. These authors originally calculated factors to convert the pyruvate thus produced into Karmen units at $25^{\circ}$ which were set equal to Reitman-Frankel units. However several investigators ${ }^{2-5}$ have been unable to show that the two sets of units are the same. Therefore there is some doubt whether the above factors for calculating enzyme activity are correct. The work to be reported here was designed to test the above aspects of the Reitman-Frankel method. 